\title{
Teoremi nemogućnosti u ekonomici zdravstva
} Impossibility theorems in health economics

\author{
Davor Mance
}

Sveučilište u Rijeci, Ekonomski fakultet, Rijeka, Hrvatska

Dopisni autor:

Doc. dr. sc. Davor Mance

Sveučilište u Rijeci, Ekonomski fakultet, Rijeka, Ivana Filipovića 4, Rijeka, Hrvatska E-mail: davor.mance@efri.hr

\begin{abstract}
Sažetak. Kolektivno odlučivanje podložno je nemogućnosti agregiranja preferencija pojedinaca u društvenu funkciju blagostanja, nemogućnosti agregiranja ordinalnih preferencija u društvenu funkciju odlučivanja te nemogućnosti agregiranja preferencija prema međusobno neusporedivim kriterijima. Ovi problemi, za koje postoje formalni teoremi dokaza, mogu imati značajne posljedice za društvo na primjeru odlučivanja u javnom zdravstvu. Metodološka nemogućnost agregiranja preferencija dodatno je uvećana etičkim problemima, što se može vidjeti iz trenutnih primjera alokacije oskudnih cjepiva. Međutim, bez nekog oblika društvenog agregiranja preferencija ili nekog oblika odlučivanja, javni sektor, pa tako i javno zdravstvo ne može obavljati svoju djelatnost. U radu se ukazuje na neke od problema koji se javljaju zbog trenutnog načina alokacije.
\end{abstract}

Ključne riječi: ekonomika zdravstva; etika; javno zdravstvo; troškovi zdravstvenog sustava

Abstract. Collective decision-making is subject to the impossibility of aggregating the preferences of individuals into a social welfare function, the impossibility of aggregating ordinal preferences into a social decision-making function, and the impossibility of aggregating preferences according to mutually incomparable criteria. These problems, for which there are formal theorems of evidence, could have significant consequences for society as for example in case of public health decision-making. Ethical issues, as can be seen from current examples of scarce vaccine allocation, exacerbate the methodological impossibility of aggregating preferences. However, without some form of social aggregation of preferences, or social decision making rules, the public sector, and thus public health systems, cannot perform their activity. This paper will try to summarize some of the problems that arise due to the current way of allocating scarce goods in health care.

Key words: ethics; health care costs; health economics; public health 


\section{UVOD}

Promatrajući javne rashode razvijenih zemalja te hijerarhijske odnose unutar organizacijskih jedinica, možemo doći do zaključka da je javno zdravstvo među najskupljim i najsloženijim javnim sustavima. Ono je prepoznatljivo po stalno rastućim apsolutnim troškovima te stalno rastućem relativnom udjelu u bruto društvenom proizvodu. Osnovni razlog rasta troškova zdravstva pripisuje se činjenici da se radi o tzv. nužnom dobru s niskom cjenovnom i dohodovnom elastičnošću potražnje. Porast dohotka stanovnika rezultira progresivnim rastom potrošnje zdravstvenih usluga, a cjenovna neelastičnost kod nužnih dobara označava spremnost za plaćanje čak i kod rastućih cijena.

Činjenica da hrvatsko stanovništvo u demografskom smislu stari, također ne ide na ruku problemu rastućih troškova zdravstva. Budući da se radi o najvećem proračunskom korisniku gotovo svih demokratskih zemalja, sustav javnog zdravstva najveći je i pojedinačni uzročnik fiskalnog deficita. Istovremeno, ne postoji konsenzus o potpunom zadovoljstvu uslugama javnog zdravstva. To $s$ jedne strane proizlazi iz osnovne ljudske psihologije neograničenosti želja, a s druge iz osnovnih organizacijskih elemenata tih sustava i nedovoljnog poznavanja ekonomskih, logičkih, matematičkih te etičkih i političkih načela na kojima su javno-zdravstveni sustavi sazdani.

Pacijenti, kao korisnici sustava javno-zdravstvenog osiguranja nisu u doticaju s troškovnom komponentom sustava te nemaju financijski poticaj da troškovno ekonomiziraju zdravstvenim uslugama. To je posljedica tzv. third-party payer sustava u kojima pacijenti ne snose troškove direktno, već troškove podmiruje treća strana. Sustav javno-zdravstvenog osiguranja, koje služi kao posrednik između pacijenata i liječnika, nije osiguranje u užem smislu te riječi. Osiguravatelj $\mathrm{i}$ osiguranik ne nalaze se u informacijski i pregovarački simetričnom položaju, odnosno u terminima „teorije igara“, ne izvlače ishode iz „poštene

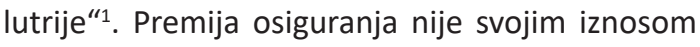
vezana uz zdravstvene rizike protiv kojih se osiguranik osigurava te ne postoji poticaj za osiguranika za manje rizičnim ponašanjem².

Sustav javno-zdravstvenog osiguranja funkcionira po javno-financijskom načelu jedinstva poreznih prihoda i rashoda. Državni proračun jamči za sve gubitke zdravstvenog proračuna te je stoga zdravstveni proračun neodvojiv od državnog. To nije izolirani slučaj Hrvatske, već svih takvih sustava u svijetu. Osim toga, zdravstveno osiguranje ne osigurava zdravlje tako da sprječava bolest, kao što ni osiguranje protiv požara ne sprječava požar. Zdravstveno je osiguranje ekonomski mehanizam preuzimanja dijela financijskog tereta troškova liječenja pacijenta, kojim se kroz vrijeme za korisnike izglađuju vremenski nizovi troškova.

Sustavi javnog zdravstva politički su sustavi zasnovani na načelu solidarnosti, pri čemu se troškovi podmiruju iz javnih proračuna. Pacijenti i liječnici nemaju poticaj za kontrolu troškova, a javno-zdravstveni sustav osiguranja mora odvagati međusobne prednosti i mane svih dostupnih zdravstvenih tehnologija i postaviti financijske granice isplativosti zahvata.

Osnovni cilj dizajna ekonomskog mehanizma jest racionalno konstruktivistički postaviti poticaje sudionika u skladu sa željenim ciljevima - kvaliteta i količina potražnje, oblici plaćanja te kvaliteta i količina ponude, odnosno liječenja.

Kompleksnost organizacije održivog centraliziranog zdravstvenog sustava ne razlikuje se od kompleksnosti uspostave centraliziranog gospodarskog sustava. Zapravo, govorimo o dijelu gospodarskog sustava koji se smatra važnijim od njegovih ostalih dijelova. Takav način razmišljanja dovodi do toga da se zaboravlja činjenica da važnost nekog sustava nije varijabla njegove kompleksnosti. I prehrana stanovništva važan je dio gospodarstva. Države koje su pokušale centralizirati organizaciju proizvodnje hrane, završile su nestašicom hrane i gladnim stanovništvom. Prema raznim izvorima u razdoblju od 1958. do 1962. godine u Narodnoj Republici Kini umrlo je između 15 i 55 milijuna ljudi kao posljedica centralizacije organizacije proizvodnje hrane 3,4, a između 1994. i 1998. godine u Narodnoj Republici Koreji od gladi je umrlo oko 500.000 ljudi $^{5,6}$. Ekvivalent nestašici hrane kod proizvodnje hrane jest nestašica lijekova i dugačke liste čekanja za liječničke preglede i liječenje u zdravstvu. Procjenjuje se da je 2016. godine od posljedica slabe kvalitete i nedostu- 
pnih javno-zdravstvenih usluga u zemljama nižeg i srednjeg dohotka umrlo preko 15 milijuna ljudi . Glad, baš kao i nedostatak lijekova i zdravstvene zaštite, u zemljama koje su ove djelatnosti stavile pod strogu državnu kontrolu, završava smrću.

Ovaj se rad bavi javno-zdravstvenim problemima koji se mogu svesti na formalno-matematičke argumente nemogućnosti postizanja konsenzusa oko alokacije unutar postojećeg sustava odlučivanja. Ti se nedostatci u ekonomiji nazivaju teoremima nemogućnosti (Condorceov paradoks, Arrowljev teorem i Senov teorem) i smatraju se teoremima dokaza protiv mogućnosti agregiranja preferencija unutar određenog skupa ograničenja koja se smatraju minimalnim.

\section{CONDORCEOV PARADOKS}

Osnovna odrednica demokratskog društvenog uređenja je sustav odlučivanja zasnovan na načelu izostanka prisile, odnosno na načelu demokratskog izbora. Markiz de Condorcet u čuvenom radu iz 1785. godine "Essai sur l'application de l'analyse a la probabilite des decisions rendues a la plurite des voix" dokazao je da tranzitivne odluke pojedinaca, kada se agregiraju u odluke većine, mogu biti društveno netranzitivne u društvu s tri ili više birača, što onemogućuje formalizaciju zaključnog suda o društvenoj preferenciji ${ }^{8}$.

Pretpostavimo da u nekom društvu postoje tri ravnomjerno raspoređene društvene skupine ljudi koje su se politički organizirale: stariji ljudi (A), ljudi srednjih godina (B) i mladi ljudi (C). Nadalje, pretpostavimo da društvo odlučuje o nabavci cjepiva protiv novog i smrtonosnog virusa. Na tržištu postoje tri cjepiva $X, Y$ i Z. Cjepivo $X$ je djelotvorno za sve dobne skupine, ali je ekstremno skupo. Cjepivo $Y$ je za nešto više od trećine cijene povoljnije, ali je $u$ odnosu na cjepivo $X$ manje djelotvorno za skupinu $A$, a na skupini $C$ nije testirano. Cjepivo $Z$ ima cijenu koja je manja od $1 / 3$ cijene cjepiva $X$, ali je i u usporedbi s učinkovitošću cjepiva $X$ značajno manje djelotvorno za skupinu A i nešto malo manje djelotvorno za skupinu B. Virusom je najugroženija najstarija društvena skupina A, slijede ljudi srednjih godina $B$, a najmanje su ugroženi pripadnici mlade grupe $C$. Društvo posjeduje javno-zdravstveni sustav koji ima dovoljno sredstava za procjepljivanje ili $1 / 3$ populacije cjepivom $X$, ili 2/3 populacije cjepivom Y, ili cijele populacije cjepivom $Z$.

Pretpostavimo da se odluka o nabavci cjepiva donosi na referendumu gdje građani mogu iskazati svoje rangove preferencija o cjepivu. Rezultati glasanja su sljedeći: skupina $A$ ima rang preferencija $X>Y>Z$, skupina $B$ preferira $Y>Z>X$, a skupina $C$ preferira $Z>X>Y$. Rezultati glasanja ne daju prednost niti jednom cjepivu zbog Condorceovog paradoksa koji se sastoji od nemogućnosti utvrđivanja društvene funkcije izbora uslijed cikličnosti preferencija birača: $X>Y>Z>X$. Vlada ipak mora donijeti nekakvu odluku pa odlučuje uspostaviti konsenzus između društvenih skupina i predložiti nabavku svih triju cjepiva tako da će rashode podijeliti ravnomjerno na sva tri cjepiva. To znači da 1/3 skupine $A$, odnosno 1/9 ukupne populacije može biti procijepljena cjepivom $X$ koje je najučinkovitije za dobnu skupinu A; polovina skupine $B$, odnosno $1 / 6$ populacije može biti procijepljena cjepivom $\mathrm{Y}$ koje je relativno učinkovito za tu dobnu skupinu te $100 \%$ skupine $C$, odnosno 1/3 populacije može biti procijepljena cjepivom Z. Na taj način 11/18 populacije, znači nešto više od pola, može biti procijepljeno uz moguće stvaranje kolektivnog imuniteta. Međutim, ova je distribucija prihvatljiva samo za one koji su dobili cjepivo iako su u njegovom financiranju, na ovaj ili onaj način, sudjelovali svi. Nadalje, cjepiva Y i Z imaju lošiju učinkovitost od cjepiva $X$ te iako je skupina $\mathrm{C} \mathrm{u}$ potpunosti procijepljena, kao i pola članova skupine $B$, učinkovito je cijepljen samo dio svake od skupina A, B ili C, što ima za posljedicu određeni broj umrlih kod svih triju društvenih skupina, ali vjerojatno najviše kod one najstarije. Etički prihvatljiva alokacija bit će samo ona u kojoj će svi biti cijepljeni najboljim i najskupljim cjepivom, a to je zbog oskudnosti cjepiva ili ograničenosti proračuna nemoguće. Pretpostavimo nadalje, da susjedna država u kojoj ima najviše pripadnika starije populacije promatra ove događaje i smatra ovakvu podjelu neetičnom i nepravednom te donosi odluku na referendumu da se nabavi isključivo najučinkovitije cjepivo i da se njime cijepe samo pripadnici najstarije društvene skupine A. Posljedica takve politike jest najveći broj oboljelih i umrlih u mlađim društvenim skupinama B i C, što dovodi do ekonomskog i socijalnog rasloja- 
vanja društva jer su to ekonomski najaktivnije društvene skupine.

Već u ovom jednostavnom primjeru imamo etički problem određenja cilja, koji bi mogao biti:

1. ravnomjerna alokacija financijskih sredstava između društvenih skupina

2. ravnomjerna alokacija cjepiva između društvenih skupina

3. ravnomjerna alokacija imuniteta između društvenih skupina

4. neki drugi cilj koji neće paziti na ravnomjernu alokaciju između društvenih skupina (to npr. može biti potpuna procijepljenost svih članova vladajuće stranke i sl.).

Vidljivo je da ne postoji neka određena politika koja bi mogla zadovoljiti sve društvene skupine i dovesti do nacionalnog konsenzusa te da niti jedan od navedenih pristupa ne može postići kolektivnu intencionalnost ${ }^{9}$. Manje poznati Condorceov teorem vezan je uz odlučivanje u poroti. Teorem kaže da ako je vjerojatnije da će svaki član porote donijeti ispravnu odluku, vjerojatnost da je najbrojniji glas ispravna odluka povećava se kako se povećava broj članova skupine. Nažalost, ovaj način odlučivanja primjereniji je kategoričkom odlučivanju gdje se traži prihvaćanje ili odbacivanje nekog prijedloga, a ne agregaciji pojedinačnih $u$ društvene preferencije.

U medicinskoj praksi koriste se preporuke za liječenje koje zahtijevaju funkciju cilja, a ona je najčešće određena proračunskim ograničenjem ${ }^{10}$. Preporuke za liječenje u sebi sadrže funkcije cilja, daju preporuke za djelovanje, ali samim time sadrže i etičke dileme koje također ponovno zahtijevaju zasebno odlučivanje i zasebnu funkciju cilja.

\section{ARROWLJEV TEOREM NEMOGUĆNOSTI}

Arrowljev teorem nešto je kompleksniji od Condorceovog i ukazuje na nepostojanje postupka kolektivnog odlučivanja koji može dosljedno pretvoriti individualne preferencije pojedinačnih članova društva u jedinstveni rang društvenih preferencija uz zadovoljenje minimalnih logičkih i etičkih uvjeta. Prema Kennethu J. Arrowu, dobitniku Nobelove nagrade iz ekonomije 1972. godine, ne postoji društvena funkcija korisnosti za neki konačan broj pojedinaca i njihovih pojedi- načnih rangova preferencija koji bi istovremeno zadovoljili pet sljedećih uvjeta ${ }^{11}$ :

1. Potpunost - postoji neki konačan broj pojedinaca u društvu (osiguranika, pacijenata) s nekim konačnim brojem preferencija (ishoda, terapija, potreba za liječenjem).

2. Tranzitivnost - ako pojedinac preferira ishod $X$ nad ishodom $Y$ te istovremeno preferira ishod $Y$ nad ishodom Z, to znači da preferira ishod $X$ nad ishodom $Z$

3. Jednoglasnost - ako svi pojedinci u društvu preferiraju ishod $X$ nad ishodom $Y$, to znači da društvo $u$ cjelini preferira ishod $X$ nad ishodom Y.

4. Nezavisnost od ostalih alternativa - ako pojedinac preferira ishod $\mathrm{X}$ nad ishodom $\mathrm{Y}$, uvođenje ishoda $Z$ ne mijenja prethodni rang preferencija između X $\mathrm{i}$ Y.

5. Nepostojanje diktatora - u društvu ne postoji ključni pojedinac čija promjena preferencije $s$ $X$ na $Y$ mijenja i društvenu preferenciju s $X$ na Y.

Drugim riječima, svako pravilo odabira za neki konačan broj pojedinaca i konačan skup njihovih rangova preferencija, koji poštuju tranzitivnost, jednoglasnost i nezavisnost preferencija, jest diktatura ${ }^{11,12}$.

Implikacija ovog teorema za bilo koji sustav javnog izbora jest nemogućnost donošenja odluka o potrebama građana u uvjetima ograničenih resursa. Upravo se ekonomija definira kao „znanost o ljudskom ponašanju u uvjetima neograničenih ljudskih želja i ograničenih resursa koji imaju alternativnu uporabu“ ili skraćeno „znanost o upravljanju oskudnim resursima“13. Pritom je potrebno naglasiti da ekonomija nikada neće dati tzv. „rješenja“ jer u ekonomskom smislu „rješenja“ ne postoje, već će ekonomija uvijek ukazati na nastali (u)trošak jedne alternative $u$ jedinicama mjere neke druge alternative kao propuštene koristi te druge alternative, što se u ekonomiji naziva oportunitetnim troškom. Taj pojam označava kompromis u obliku mogućnosti većeg zadovoljenja jedne potrebe nauštrb zadovoljenja neke druge potrebe. Osnovni je problem u tome što korisnosti nisu interpersonalno usporedive, a nije moguće niti njihovo agregiranje u društvenu funkciju korisnosti jer ne postoji jedinica mjere za 
korisnost. Jedina operacija koja je izvediva jest da svatko za sebe rangira vlastite intrapersonalne alternative prema subjektivno percipiranoj a priori korisnosti. U svakom drugom slučaju dolazi do prisilnog imputiranja tuđih preferencija, odnosno kako se to u ekonomici blagostanja naziva - postojanje diktatora.

Međutim, Arrowljev teorem nemogućnosti ne vrijedi za kardinalne sustave izbora kakvo je npr. slobodno tržište organizirano oko cjenovne alokacije oskudnih dobara ${ }^{14,15}$. Radovi koji se bave agregiranjem individualnih preferencija unutar nekog društvenog poretka, pomoću definiranog aksiomatskog okvira danas su mnogobrojni te postoji i posebna grana unutar operacijskih istraživanja kao grane matematike koja se bavi donošenjem odluka pod uvjetom istovremene optimizacije više suprotstavljenih kriterija - višekriterijsko odlučivanje (engl. Multiple Criteria Decision Making, MCDM). Osnovna mana cijele ove grane matematike i dalje ostaje ista kao i kod Arrowljevog teorema nemogućnosti - diktator je onaj koji donosi pravila agregiranja preferencija jer o tim pravilima ovisi konačan rezultat. S etičkog stajališta, ovo je bolje rješenje jer barem zadovoljava kriterije konzekvencionalističke (utilitarističke) etike pravila. Konzekvencionalizam pravila vrednuje postupke indirektno - pravila se kreiraju imajući na umu njihove konačne posljedice, ali su pravila ta kojih se pridržavamo te se tako djelomično gubi diskrecijski odnos između tvorca pravila kao diktatora i subjekta, a samim time i sukob interesa ${ }^{16}$. Izostanak sukoba interesa pritom ne opravdava konzekvencionalizam pravila u obliku višekriterijskog odlučivanja u alokaciji oskudnih resursa jer problem postojanja diktatora i dalje ostaje.

\section{MORALNI HAZARD U JAVNOM ZDRAVSTVU}

Donošenje odluka u zdravstvu nije informacijski simetrično niti na jednoj razini, odnosno niti u jednom od odnosa između triju aktera: pacijenta, liječnika i osiguravatelja. To je posljedica različitih tržišnih odnosa između pacijenta, liječnika i osiguravatelja, različite profesionalne izobrazbe pacijenta i liječnika te učestalosti izloženosti sličnim situacijama u prošlosti, gdje su sudionici na različite načine internalizirali ponašanje drugih sudionika.
Moralni hazard u zdravstvu jest posljedica informacijske asimetrije između pacijenta osiguranika koji posjeduje informacije o svom zdravlju i osiguravatelja; liječnika kao osobe koja je provela najdulje vremena specijalizirajući se u struci te na taj način stekla i najveću informacijsku prednost; odstupanja interesa osiguranika i osiguravatelja te konačno odstupanja interesa liječnika, osiguravatelja i osiguranika. Moralni se hazard očituje u povećanju troškova zdravstva u sustavu potpunog zdravstvenog osiguranja ${ }^{17,18}$. Osobe koje imaju potpuno osiguranje protiv neke štete, promijenit će svoje ponašanje s obzirom na sprječavanje te štete, a osobe koje imaju financijsko pokriće za višu razinu i količinu usluga, težit će to i iskoristiti. U sustavu s potpunim zdravstvenim osiguranjem pojedinci će se ponašati rizičnije i trošit će više zdravstvenih usluga nego što bi to činili kada bi svaki put morali sami platiti.

2008. godine je u američkoj saveznoj državi Oregon proveden eksperiment u kojem je slučajnim odabirom (lutrijom) grupi od 10.000 prethodno neosiguranih osoba dodijeljeno zdravstveno osiguranje za osobe s nižim dohotkom (Medicaid) ${ }^{17}$. $\mathrm{Na}$ taj su način ekonomisti na velikom uzorku mogli doći do statistički značajnih zaključaka vezanih uz utjecaj zdravstvenog osiguranja na potrošnju u zdravstvu uspoređujući uzorak pacijenata iz grupe od 10.000 slučajno odabranih osiguranika s kontrolnom grupom neosiguranih pacijenata. Dakle, možemo govoriti o djelomično kontroliranom statističkom eksperimentu u kojem su obuhvaćeni isključivo pacijenti podijeljeni u dvije grupe: osigurani i neosigurani. Rezultati istraživanja pokazali su da su pripadnici osigurane skupine imali $30 \%$ povećane odlaske u bolnicu, $35 \%$ povećane posjete liječnika kod kuće, $15 \%$ povećano uzimanje lijekova na recept i $40 \%$ povećane posjete hitnoj pomoći u odnosu na skupinu neosiguranih osoba. Nadalje, osigurana grupa ne samo da je češće koristila zdravstveni sustav (25 \%) već je koristila i skuplje zdravstvene usluge, uključujući usluge primarne i preventivne zaštite, kao i hospitalizacije, što je za osiguranike osobno značilo niže troškove liječenja i niži dug, uz izbjegavanje izdvajanja za zdravstvene usluge koje prelaze $30 \%$ godišnjeg dohotka, a koje se u SAD-u smatraju katastrofalnim. Konačno, sve je to rezultiralo bo- 
ljim tjelesnim i mentalnim zdravljem osigurane skupine u odnosu na kontrolnu skupinu, ali isto tako i povećanjem ukupnih troškova liječenja za $25 \%$ u odnosu na kontrolnu skupinu ${ }^{17}$. Ovaj eksperiment potvrđuje statistike povećanja troškova zdravstva za $40 \%$ tijekom pet godina nakon uvođenja zdravstvenog osiguranja za starije od 65 godina (Medicare) u SAD-u, na što je upozoravalo jedno ranije istraživanje koje je provela RAND korporacija ${ }^{19}$. Također, ovaj eksperiment, zbog slučajnog odabira uzorka i kontrolne skupine, daje kvalitetnije rezultate od izoliranog promatranja ponašanja pojedinačnih pacijenata. Za razliku od individualiziranih kliničkih ispitivanja, koja imaju velike prednosti u medicini, promatranje odvojenih slučajno odabranih uzoraka osiguranih i neosiguranih osoba, daje dodatne informacije o svim vrstama moralnog hazarda.

Moralni hazard u zdravstvenom osiguranju moguće je podijeliti:

1. a priori moralni hazard koji se sastoji od promjena u ponašanju osiguranika nakon što je pribavio zdravstveno osiguranje, ili je pribavio bolje zdravstveno osiguranje

2. a posteriori moralni hazard koji se sastoji od povećane potrošnje zdravstvenih usluga kada su one potrebne, kod osiguranika kojima to njihovo osiguranje dozvoljava

3. sustavni moralni hazard koji se sastoji od financijskog interesa liječnika da svojim pacijentima naručuje skuplje zdravstvene tehnologije i prepisuje skuplje lijekove.

Na moralni hazard utječe institucionalni i organizacijski dizajn sustava. Institucije su pravila i norme kojima se utječe na ljudsko ponašanje, prije svega na stvaranje povjerenja u smislu očekivanja posljedica ljudskog djelovanja ${ }^{20}$. Na taj način institucije umanjuju transakcijske troškove i omogućavaju slobodnu ljudsku interakciju i umrežavanje. Organizacije su strukturirane ljudske hijerarhije koje su stvorene s ciljevima zaobilaženja rezidualnih transakcijskih troškova te stvaranja učinkovitijih i ekonomičnijih sustava ${ }^{21}$. Između institucionalno uređenih slobodnih ljudskih mreža i hijerarhijski uređenih organizacija postoje odnosi komplementarnosti i sukoba. Komplementarnost nastaje kada organizacije zbog svoje učinkovitosti i ekonomičnosti štede oskudne resurse i dio viška vrijednosti predaju društvu u obliku nižih cijena i/ili povećane količine i/ili kvalitete svojih proizvoda i usluga. Sukob nastaje uslijed želje organizacija da isključe sve ostale s tržišta, odnosno da stvore monopol.

Teoremi nemogućnosti imaju posljedice za bilo koju vrstu višekriterijskog kolektivnog odlučivanja te stoga predstavljaju predmet istraživanja ne samo u društvenim znanostima (ekonomiji, politologiji i pravu) već i u medicini. Neshvaćanje teorema nemogućnosti ima za posljedicu alokaciju medicinskih resursa koja je suboptimalna za određene pojedince.

\section{TEORIJA DRUŠTVENOG IZBORA AMARTYE SENA}

Teorija društvenog izbora bavi se načinima na koje društva agregiraju individualne u kolektivne preferencije ${ }^{22}$. Najviše problema u razvoju teorije društvenog izbora proizlazi iz pokušaja da se svi problemi pojedinačnih teorija društvenog izbora riješe jednom općom i sveobuhvatnom teorijom društvenog izbora. Prema Senu, rješenje je u podjeli i klasifikaciji teorija društvenog izbora u ovisnosti o tome koji se podatci agregiraju ${ }^{22}$.

Sen razlikuje dvije vrste ocjena:

a) ocjene o smjeru djelovanja kao samom činu deontološke etike (o njima se najčešće odlučuje u povjerenstvima, a odluke se uglavnom donose većinom glasova)

b) ocjene o društvenom blagostanju kao cilju konzekvencionalističke etike (analiziraju se utjecaji na ukupno blagostanje društva te na pojedince, gdje se nekima blagostanje povećava a nekima smanjuje, takve se odluke uglavnom izražavaju binarno $s$ „ $X$ je bolje od $\left.Y^{\prime \prime}\right)$.

Obje vrste ocjena zahtijevaju mjerenje indikatora blagostanja kao npr. morbiditeta, bogatstva, dohotka, nejednakosti i sl. Amartya Sen uspješno je pokazao da su ove mjere interpersonalno neusporedive, odnosno da se ne mogu upotrijebiti za učinkovito donošenje navedenih ocjena ${ }^{23}$.

Sljedeći je problem vaganja pojedinačnih mjera blagostanja s obzirom na jačinu individualnih preferencija i kretanja između dvaju različitih nivoa 
korisnosti. Senova analiza u ovom je području isključivo formalne naravi, a etička se pitanja unose $u$ formalne modele u obliku uvjeta. Sen pokušava izvesti društvenu funkciju odlučivanja i društvenu funkciju blagostanja iz individualnih funkcija. Pritom, Sen ni na koji način ne rangira uvjete, odnosno formalna ograničenja koja su normativnog sadržaja na način kako bi to npr. jedan pravni sustav rangirao ${ }^{22-25}$. Time se u potpunosti isključuje mogućnost da su i sama pravila društvenog izbora na neki način ujedno i kolektivne preferencije očekivanih društvenih stanja nakon izbora. Osnovno polazište jest ideja da moralno načelo ima nedostatke:

1. kada se uporabom tog načela značajno odstupa od željenih posljedica

2. kada se dokaže inkonzistencija načela njegovom supsumcijom pod neko općenitije načelo.

Sen zaključuje da se niti jedno pravilo ne može smatrati općim etičkim načelom ${ }^{22}$.

Konačno, Sen formalno dokazuje da ne postoji društvena funkcija odlučivanja koja bi istovremeno mogla zadovoljiti sljedeće i u odnosu na Arrowa blaže uvjete zasnovane na etičkim načelima:

1. Neograničenost individualnih preferencija to je zahtjev koji sprječava arbitrarno ograničavanje individualnih setova preferencija. Sve poznate i moguće kombinacije preferencija mogu biti predmet odlučivanja.

2. Slabo liberalno načelo jednoglasnosti - ako svaki pojedinac u društvu preferira stanje $x$ nad $y$, onda i društvo u cjelini preferira stanje $x$ nad $y$.

3. Nepostojanje diktatora u Arrowljevom smislu.

Za razliku od Arrowa koji je dokazao nemogućnost agregiranja individualnih preferencija $u$ društvenu funkciju blagostanja zasnovanu na pet jednostavnih i prihvatljivih načela, Sen dokazuje nemogućnost agregiranja individualnih preferencija u društvenu funkciju odlučivanja s još jednostavnijim setom još prihvatljivijih načela, gdje za razliku od Arrowa, Sen ne zahtijeva ni tranzitivnost preferencija niti nezavisnost od nerelevantnih alternativa. Prema Senu, „garancija individualnih sloboda ne počiva na pravilima društvenog izbora, nego na razvoju pojedinačnih vrijednosti koje poštuju individualni izbor “22. Senov paradoks na- staje kada pojedinci „zabadaju nos u tuđe preferencije“22 te kada nečije djelovanje ovisi o tuđem djelovanju. Ovo drugo u ekonomiji nazivamo negativnim eksternim ekonomijama koje su posljedica nepotpunosti vlasničkih prava i nemogućnosti internalizacije eksternalija kompenzacijom. U našem primjeru s cjepivima, do paradoksa ne dolazi ako svaki pojedinac za sebe kupuje cjepivo koje mu najviše odgovara.

\section{POSLJEDICE PO JAVNO-ZDRAVSTVENE} SUSTAVE

Korist od neke zdravstvene tehnologije često je višedimenzionalna konstrukcija i zahtijeva ocjenu različitih kriterija. MCDM pokušava sustavno i transparentno integrirati preferencije, vrijednosne prosudbe, prioritete i sklonosti pacijenata, osiguranika i stručnjaka u proces donošenja odluka. Međutim, MCDM je holistički konstrukt koji zanemaruje individualne preferencije. Kako usuglasiti trade-off između produljenja ljudskog života jedne osobe i poboljšanja kvalitete života druge osobe?

U Ujedinjenom Kraljevstvu koje ima potpuno socijalno zdravstvo, prema preporukama NICE-a (National Institute for Clinical Excellence) pacijentima starijima od 70 godina neće biti transplantiran vitalni organ, već će takav pacijent biti upućen na palijativnu njegu. U Sjedinjenim Američkim Državama takav će pacijent dobiti šansu. Ovakva se razlika u odlukama opravdava utilitarističkom etikom koja je svoju radikalnu primjenu našla u QALY-jima (Quality Adjusted Life Years) indeksom koji kvaliteti života prilagođava godine života, gdje jedinica (1) označava godinu dana provedenu u savršenom zdravlju, a nula (0) označava smrt. Kvaliteta života nekog kroničnog bolesnika u određenim bi se okolnostima npr. mogla ocijeniti s 0.8 , što bi značilo da taj pacijent ima za $20 \%$ umanjenu kvalitetu života u odnosu na čovjeka savršenog zdravlja. Budući da se radi o agregiranim ordinalnim izrečenim preferencijama ispitanika, sve ono što je izrečeno u teoremima nemogućnosti, vrijedi i za QALY-je iako QALY-ji ne predstavljaju konačnu korisnost ${ }^{26}$. QALY-ji koji se konstruiraju na bilo koji drugi način osim lutrijom, prema definiciji ne mogu biti korisnosti ${ }^{1}$. Također, QALY-ji su nepouzdani jer u ovisnosti od 
metode prikupljanja podataka, rezultati mogu značajno odstupati ${ }^{26}$.

Arrowljev je formalni dokaz da je agregiranje individualnih preferencija u društveni poredak nemoguće, osim ako se ne odstupi od nekih opće prihvatljivih načela. Problem odlučivanja u javnom je sektoru višeslojan i sastoji se od najmanje triju za sada nepremostivih prepreka.

Prvi je problem agencijski problem, koji se sastoji od činjenice da su kriteriji odlučivanja pomoću kojih agent (npr. parlament, vlada, povjerenstvo za lijekove i sl.) odlučuje u ime i za korist principala (građani, pacijenti) odraz mišljenja agenta. Ovaj se problem ne umanjuje zamjenom agenta pojedinca povjerenstvom, već se problem time samo premješta na višu razinu odlučivanja, od koje se očekuje da je bolje informirana za donošenje odluka, čime se jedne informacijske asimetrije zamjenjuju drugima. Nije li jednostavnije informirati principala?

Drugi se problem sastoji od Arrowljevog teorema nemogućnosti agregiranja individualnih preferencija u društvenu funkciju preferencija i Senovog teorema nemogućnosti kolektivnog odabira.

Treći se problem sastoji od nemogućnosti donošenja odluka u situacijama u kojima se svaka preferencija sastoji od više pojedinačnih i međusobno teže usporedivih kriterija.

Kao primjer možemo uzeti u obzir posljedice odluka povjerenstva za lijekove ili u slučaju pandemije COVID-a 19, odluke „stožera“. Ova se problematika svrstava u područje „moralne teorije politike“, odnosno „ekonomske etike“ s obzirom na to da se odluka o alokaciji oskudnih dobara svodi na neko etičko načelo.

Moralna teorija politike još se od najranijih začetaka u prosvjetiteljstvu bavi pokušajem da se politici pristupi znanstveno, imajući na umu zadaću povećanja dobrobiti najvećeg mogućeg broja ljudi uz pridržavanje osnovnih ljudskih prava. Kao što vidimo iz Arrowljevog i Senovog teorema, to nije moguće ako se ne prekrši barem jedno od željenih načela. Jedno od mogućih rješenja ovog problema jest ekonomska, tržišna alokacija oskudnih medicinskih dobara. Međutim, najčešći je prigovor tržištu da je neetično, odnosno da načelo ekonomske efikasnosti pretpostavlja moralnim načelima jer će uvijek postojati oni koji zbog neimaštine ne mogu ravnopravno sudjelovati u tržišnoj alokaciji. Umjesto osnaživanja njihove tržišne pozicije maksimirajući poziciju najsiromašnijih, pribjegava se nacionalizaciji cjelokupnog zdravstvenog sustava dvostruko narušavajući tržišne poticaje: u ponudi i u potražnji.

$\mathrm{Na}$ primjer, maksimizacija društvene korisnosti postiže se izjednačavanjem granične korisnosti svih pojedinaca u društvu. To je postignuto kada je granični probitak dobitnika jednak graničnom trošku gubitnika. Prevedeno na QALY-je, utilitaristički je opravdano usmjeriti oskudne zdravstvene resurse prema bogatom i mladom pacijentu koji će više povećati svoje QALY-je, a zanemariti siromašnog kroničnog bolesnika. Nije li takav ishod upravo normativno suprotan početnim razlozima za uvođenje socijalnog zdravstva?

Socijalno zdravstvo zasnovano na ordinalnim rangovima preferencija (QALY-jima) ne može čak niti teoretski zadovoljiti minimalne uvjete za uspostavu društvene funkcije blagostanja ili odlučivanja. Da bi to bilo moguće, potreban je kardinalni sustav s mogućnošću interpersonalne usporedbe. Sustav s kardinalnim novčanim jedinicama zadovoljavao bi teoretske pretpostavke takvog modela, a to zahtijeva privatizaciju sustava bez dirigiranih cijena. Međutim, čak i u SAD-u, gdje je najveći dio zdravstvenog sustava dio slobodnog privatnog sustava, postoji cijeli niz reguliranih cijena kroz Medicare i Medicaid programe namijenjene starijima i siromašnima. Ukupni troškovi zdravstva u SAD-u danas se kreću oko $18 \%$ BDP-a ${ }^{27}$. Dobar dio povećanih troškova može se objasniti značajnijom cjenovnom inflacijom uslijed povećane potražnje za zdravstvenim uslugama i nemogućnosti da se potražnja kratkoročno zadovolji te znatno većim bogatstvom i dohotkom nacije koja je spremna skrbiti za siromašne (Medicaid) i stare (Madicare) putem značajnog proračunskog subvencioniranja. Oko četvrtine ukupnog iznosa potrošnje u javno-zdravstvenom sustavu Medicaid može se svesti na neučinkovitost institucionalnog mehanizma dizajna sustava koji nije uspješan u eliminiranju „moralnog hazarda“"17,18. Istraživanje provedeno u Oregonu otkriva nam da se po svojim ekonomskim svojstvima tržište zdravstvenih usluga ne razlikuje od ostalih tržišta, a tržište zdravstvenog osiguranja ne razli- 
kuje se od drugih tržišta osiguranja ${ }^{17}$. To znači da svi mehanizmi dizajna poticaja poznati iz ostalih tržišta osiguranja - kao npr. samopridržaj, participacija te popusti i nagrade, vrlo vjerojatno mogu pomoći u rješavanju agencijskih problema moralnog hazarda i negativne selekcije. U tom je smislu potrebna integracija većeg broja stručnjaka iz različitih područja znanosti kod reforme hrvatskog zdravstvenog sustava.

\section{ZAKLJUČAK}

Osnovni problem ekonomije definira se kao problem alokacije oskudnih resursa između alternativnih potrošnji. Oskudnost, odnosno nemogućnost zadovoljenja svih potreba u društvu nameće nužne izbore odnosno pravila alokacije. Teoremi nemogućnosti matematički dokazuju nemogućnost agregiranja pojedinačnih ordinalnih funkcija preferencija u jedinstvenu društvenu funkciju blagostanja, uz nužno zadovoljenje minimalnih matematičkih, logičkih i etičkih kriterija. Ova nemogućnost ne vrijedi za kardinalne intersubjektivno usporedive funkcije, kao što je npr. sustav tržišnih cijena. Međutim, ti se sustavi smatraju duboko neetičnima. Neki zdravstveni sustavi tome pristupaju na način da je bolja zdravstvena skrb dostupna onima koji za to mogu prikupiti potrebna sredstva (izravnim davanjem ili sveobuhvatnim privatnim osiguranjem), a drugi se baziraju na QALY-jima ili sličnim metodama te tako nastoje preferirati tretmane koji iskazuju veću korisnost za društvo. Veća korisnost za društvo ne znači i veću korisnost za ciljanog pojedinca. Implikacije teorema nemogućnosti na ekonomski dizajn sustava jesu nužnost privatizacije ponude zdravstvenih usluga, ali i potražnje kroz privatizaciju sustava zdravstvenog osiguranja s uspostavom tržišnih cijena i konkurencije. Veća uloga kardinalnih (monetarnih) informacija u takvom sustavu omogućava i veće korištenje monetarnih mehanizama dizajna poticaja poznatih s ostalih tržišta, a posebno s tržišta osiguranja. Niti jedan zdravstveni sustav u svijetu nema resurse koji bi omogućili pružanje najbolje zdravstvene njege za sve stanovnike. Oskudnost resursa uvijek rezultira potrebom za donošenjem odluke koja će po nekoga, nažalost, biti nepovoljna. Ono u čemu ekonomika zdravstva može pomoći, jest dizajnirati mehanizme koji će omogućiti najbolje liječenje najvećem broju ljudi s obzirom na navedena ograničenja.

\section{Zahvale}

Zahvaljujem se anonimnim recenzentima na korisnim komentarima. Ovaj rad primio je potporu Sveučilišta u Rijeci: uniri-drustv-18-284-1456.

Izjava o sukobu interesa: Autor izjavljuje kako ne postoji sukob interesa.

\section{LITERATURA}

1. von Neumann J; Morgenstern O. Theory of games and economic behaviour. Princeton: Princeton University Press, 1944.

2. Arrow K J. Uncertainty and the welfare economics of medical care. Am Econ Rev 1963;53:941-973.

3. Smil, V. China's great famine: 40 years later. BMJ 1999; 319:1619-1621.

4. Gráda, CÓ. Making Famine History. J Econ Lit 2007;45: 5-38.

5. Noland, M. Famine and Reform in North Korea. Asian Econ Papers 2004;3:1-40.

6. Haggard, S; Nolan, M. Famine in North Korea. Columbia University Press, 2007.

7. Kruk ME, Gage AD, Naima JT, Danaei G, García-Saisó S, Salomon JA. Mortality due to low-quality health systems in the universal health coverage era: a systematic analysis of amenable deaths in 137 countries. Lancet 2018; 392:2203-12.

8. Marquis de Condorcet. Essai sur l'application de l'analyse à la probabilité des décisions rendues à la pluralité des voix, 1785.

9. Searle JR. What is an Institution? J I Econ 2005;1:1-22.

10. Mance D, Mance D, Vitezić D. Incremental costeffectiveness pharmacoeconomic assessment of hepatitis $C$ virus therapy: an approach for less wealthy members of the common market. Croat Medical J 2016;57:582-590.

11. Arrow KJ. A Difficulty in the Concept of Social Welfare. J Polit Econ 1950;58:328-346.

12. Geanakoplos J. Three brief proofs of Arrow's Impossibility Theorem. Econ Theor 2005;26:211-215.

13. Robbins L. An Essay on the Nature and Significance of Economic Science. London: Macmillan, 1935.

14. Debreu G. A social equilibrium existence theorem. P Natl Acad Sci 1952;38:886-893.

15. Arrow KJ, Debreu G. Existence of an Equilibrium for a Competitive Economy. Econometrica 1954;22:265-290.

16. Berčić B. Filozofija, sažeto e-izdanje. IBIS grafika, Zagreb, 2012. Dostupno na: https://bib.irb.hr/datoteka/546996. Bercic_Filozofija_e-izdanje.pdf.

17. Finkelstein AN, Taubman S, Wright B, Bernstein M, Gruber J, Newhouse J P et al. The Oregon Health Insurance Experiment: Evidence from the First Year. Q J Econ 2012;127:1057-1106.

18. Taubman SL, Allen HL, Wright BJ, Baicker K, Finkelstein AN. Medicaid Increases Emergency-Department Use: 
Evidence from Oregon's Health Insurance Experiment. Science 2014;343:263-268.

19. Aron-Dine A, Einav L, Finkelstein A. The RAND Health Insurance Experiment, Three Decades Later. J Econ Perspect 2019;27:197-222.

20. North DC. Institucije, institucionalna promjena i ekonomska uspješnost. Zagreb: Masmedia, 2003.

21. Coase R. The Nature of the Firm. Economica 1937; 4:386-405.

22. Amartya S. The Impossibility of a Paretian Liberal. J Pol Econ 1970;78:152-157.

23. Amartya S. Rationality and Social Choice. Am Econ Rev 1995;85:1-24.
24. Amartya S. Personal Utilities and Public Judgements: Or What's Wrong With Welfare Economics? Econ J 1979;89: 537-558.

25. Amartya S. The Possibility of Social Choice. Am Econ Rev 1999;89:349-378.

26. Drummond MF, Sculpher MJ, Claxton K, Stoddart GL, Torrance GW. Methods for the Economic Evaluation of Health Care Programmes. Oxford: Oxford University Press, 2015.

27. Keehan SP, Cuckler GA, Poisal JA, Sisko AM, Smith SD, Madison AJ. National Health Expenditure Projections, 2019-28: Expected Rebound In Prices Drives Rising Spending Growth. Health Affair 2020;39:704-714. 